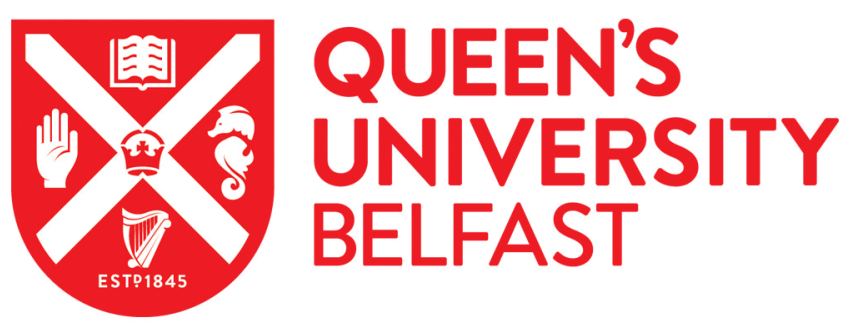

\title{
Combining Bio- and Chemo-Catalysis for the Conversion of Bio- Renewable Alcohols: Homogeneous Iridium Catalysed Hydrogen Transfer Initiated Dehydration of 1,3-Propanediol to Aldehydes
}

Wang, Y-M., Lorenzini, F., Rebros, M., Saunders, G. C., \& Marr, A. C. (2016). Combining Bio- and ChemoCatalysis for the Conversion of Bio-Renewable Alcohols: Homogeneous Iridium Catalysed Hydrogen Transfer Initiated Dehydration of 1,3-Propanediol to Aldehydes. Green Chemistry, 18(6), 1751-1761.

https://doi.org/10.1039/C5GC02157J

\section{Published in:}

Green Chemistry

Document Version:

Peer reviewed version

Queen's University Belfast - Research Portal:

Link to publication record in Queen's University Belfast Research Portal

\section{Publisher rights}

(c) 2015 The Author, published by The Royal Society of Chemistry

\section{General rights}

Copyright for the publications made accessible via the Queen's University Belfast Research Portal is retained by the author(s) and / or other copyright owners and it is a condition of accessing these publications that users recognise and abide by the legal requirements associated with these rights.

Take down policy

The Research Portal is Queen's institutional repository that provides access to Queen's research output. Every effort has been made to ensure that content in the Research Portal does not infringe any person's rights, or applicable UK laws. If you discover content in the

Research Portal that you believe breaches copyright or violates any law, please contact openaccess@qub.ac.uk. 


\title{
Combining Bio- and Chemo-Catalysis for the Conversion of Bio-Renewable
} Alcohols: Homogeneous Iridium Catalysed Hydrogen Transfer Initiated Dehydration of 1,3-Propanediol to Aldehydes

\author{
Yue-Ming Wang, ${ }^{\text {a, }}$ Fabio Lorenzini, ${ }^{\text {a }}$ Martin Rebros, ${ }^{\mathrm{c}}$ Graham C. Saunders, ${ }^{\mathrm{d}}$ \\ and Andrew C. Marr.* ${ }^{\mathrm{a}, \mathrm{b}}$ \\ ${ }^{a}$ School of Chemistry and Chemical Engineering, Queen's University of Belfast, UK. \\ ${ }^{b}$ Queen's University Ionic Liquids Laboratories (QUILL), UK. \\ ${ }^{c}$ Institute of Biotechnology and Food Science, Faculty of Chemical and Food Technology, \\ Slovak University of Technology, Bratislava, Slovakia. \\ ${ }^{d}$ School of Science, The University of Waikato, Hamilton 3240, New Zealand. \\ *a.marr@qub.ac.uk
}

\begin{abstract}
.
Combining whole cell biocatalysis and chemocatalysis in a single reaction sequence avoids unnecessary separations, and the associated waste and energy consumption. Bacterial fermentation has been employed to convert waste glycerol from biodiesel production into 1,3-propanediol. This 1,3-propanediol can be extracted selectively from the aqueous fermentation broth using ionic liquids. 1,3-propanediol in ionic liquid solution was converted to propionaldehyde by hydrogen transfer initiated dehydration (HTID) catalysed by a $\mathrm{Cp}^{*} \mathrm{IrCl}_{2}(\mathrm{NHC})\left(\mathrm{Cp}^{*}=\right.$ pentamethylcyclopentadienyl; $\mathrm{NHC}=$ carbene ligand $)$ complex. The use of an ionic liquid solvent enabled the reaction to be performed under reduced pressure, facilitating the isolation of the product, and improving the reaction selectivity. The Ir(III) catalyst in ionic liquid was found to be highly recyclable.
\end{abstract}

\section{Introduction.}

The success of the oil and petrochemical industries can be attributed to the production of transportable fuels in parallel with the synthesis of chemicals, and in particular precursors to polymers and materials. Of the alternatives to fossil fuel energies, only biomass presents similar opportunities, and by analogy the production of biofuels is rendered more economical by coupling it to the production of chemicals from biomass, for example in a biorefinery. The conversion of food producing land to energy crops is understandably controversial, and should be avoided. More sustainable is the production of fuels from agricultural and food wastes. These wastes are ubiquitous, as all animals must eat, and therefore their utilisation provides real opportunities to develop low waste, highly sustainable industries. In Europe 
used fats and oils are being upcycled into biodiesel in industrial plants on 100 thousand ton per annum scale. Biodiesel is a transportable bio-derived fuel, but production generates waste glycerol. This provides opportunities to introduce parallel chemicals production, but unfortunately the crude glycerol formed is a difficult substrate, as it is highly contaminated and very wet. The conversion of impure bio-renewable starting materials into valuable chemical products is a significant challenge. ${ }^{1}$ Low cost starting materials available from biomass are, in general, very different from those derived from fossil fuels, and tend to be highly oxygenated, impure, aqueous, and dilute. These solutions of mixed aqueous oxygenates require purification from water and deoxygenation. This is in stark contrast to hydrocarbons, which require oxidation in their primary processing. As a result, the methods that have been developed for crude oil streams are not suitable for the treatment of biomass feeds, and a new generation of transformations and processes is required.

Whole cell biocatalysis provides a route by which crude biomass feeds can be mobilized. Bacteria, algae and fungi can be used to convert oxygenates at low concentration in impure aqueous solution into solutions rich in target chemicals. ${ }^{2}$ A whole cell catalyst digests organic material and enriches the solution in the side-products of metabolism. Common products are alcohols and carboxylic acids. Coupling whole cell biocatalysis to downstream chemocatalytic transformations widens the variety of chemicals that can be prepared. ${ }^{3}$

1,3-propanediol (1,3-PDO) is a renewable platform chemical ${ }^{1}$ that can be readily prepared by large scale whole cell biocatalysis. ${ }^{2}$ Bio-derived 1,3-propanediol is currently produced by the bacterial fermentation of sugars. ${ }^{2,4} 1,3-\mathrm{PDO}$ can be obtained at competitive cost and is commercially available from DuPont ${ }^{\mathrm{TM}}$ (marketed as Bio-PDO ${ }^{\mathrm{TM}}$ ). ${ }^{4}$

Although it is difficult to generate from biomass by chemical means, fermentative production of 1,3-PDO is relatively simple and environmentally friendly. ${ }^{5} 1,3-\mathrm{PDO}$ is also a major product of glycerol fermentation employing many microbial species such as Clostridium, ${ }^{6}$ Klebsiella, Citrobacter, ${ }^{7}$ Lactobacillus, ${ }^{8}$ and of genetically modified microorganisms. ${ }^{9}$ The low crude glycerol price could lead to these feeds becoming the preferred substrates for microbial 1,3-PDO production. Since our report ${ }^{10}$ on the combination of Clostridium butyricum activity with hydrogen transfer chemocatalysis to convert crude glycerol from biodiesel production, further studies focused on direct crude glycerol fermentations have been reported. ${ }^{11,12,13}$ The conversion of glycerol to 1,3-PDO employs two enzymatic steps: glycerol dehydratation by glycerol dehydratase to 3hydroxypropionaldehyde, and its further reduction to 1,3-PDO by NADH dependent 1,3propanediol oxidoreductase. ${ }^{9}$ This reductive metabolic pathway is used by microorganism to 
maintain the steady state concentration of NADH and $\mathrm{NAD}^{+}$cofactors. ${ }^{9,13}$ Concentrations as high as $93.7 \mathrm{~g} / 1$ of 1,3-PDO from pure and $76.2 \mathrm{~g} / 1$ of 1,3-PDO from crude glycerol with productivities of 3.3 and $2.3 \mathrm{~g} / \mathrm{l} \cdot \mathrm{h}$, respectively, have been reported ${ }^{11}$ for fed-batch anaerobic production by Clostridium butyricum isolates. The main bottleneck of fermentative production of 1,3-PDO and its further applications for chemical catalysis is the formation of by-products such as butyrate, ethanol and acetate. ${ }^{5}$ These products contaminate the fermentation broth and complicate the downstream processing, and further developments are required on the isolation of the products of whole cell biocatalysis.

Following this biocatalytic step, the intermediate chemical must be extracted from the aqueous solution and converted into a marketable chemical. Extraction from water can be difficult and expensive, particularly as the chemicals generated often have high water solubility, and this has led to research into the application of newer solvent technologies. In the field of bio-renewable alcohol extraction from aqueous solution ionic liquids are showing considerable promise. Ionic liquids exhibit the dual advantages of tuneable physical properties, and high affinity for alcohols. The functional groups comprising the cation and anion can be tuned to alter solvent properties, and hydrophobic ionic liquids can be prepared. ${ }^{14}$ Hydrophobic ionic liquids still have excellent solubilising properties for polar organics; this enables the biphasic extraction of fermentation broth to be set up. The efficient extraction of bio-butanol has been demonstrated using imidazolium ${ }^{15}$ and phosphonium ${ }^{16}$ ionic liquids, and the optimisation of 1,3-propanediol extraction is ongoing in several research groups, including Marr and co-workers (X. Liu et al unpublished work). Varying the class of cation or anion, and even the functionality for a given ionic liquid type, changes the properties of extraction markedly. For ionic liquids that are not sufficiently hydrophobic, the addition of salts to the aqueous phase can yield biphasic mixtures to enable oxygenated targets to be selectively extracted. ${ }^{17-20}$ Recently this approach has been applied to the removal of 1,3-propanediol from fermentation broths. ${ }^{21,22}$

Once extracted into the ionic liquid, the desired organic product must be isolated. Extraction with a volatile organic solvent will render the initial extraction barely worthwhile! However, the primary product of fermentation is rarely the desired chemical target, and can be viewed as a chemical intermediate. Coupling biocatalysis with a downstream chemocatalytic reaction without intermediate isolation can avoid separation problems. ${ }^{3,10}$ Industrial scale fermentations to yield chemicals tend to be large. If a sufficient concentration of the product can be obtained, the aqueous solution could be drawn off and converted to chemical products or fuels as required. Ideally the extraction, downstream reaction, and 
product removal will not contaminate the fermentation broth, and will render it recyclable, therefore conserving water. In a special case a functional ionic liquid could act as the extracting solvent and catalyst for chemical change, ${ }^{22}$ but instances in which the catalyst and extraction solvent optimise coincidently will be exceptional. Alternatively the addition of a catalyst to the extracting solvent is acceptable, provided the catalyst does not leach into the aqueous solution.

New chemocatalytic transformations that can be coupled to biocatalytic 1,3-PDO production are being investigated by Marr and co-workers. ${ }^{3,10,23}$ Of specific interest is the potential of hydrogen transfer and dehydrogenation catalysts to transform bio-renewable alcohols into value added chemicals. ${ }^{24,25}$

Reactions that involve the transfer of hydrogen from one organic donor to another (sometimes termed "hydrogen borrowing" reactions) have huge potential in organic synthesis, and have been the subject of several recent reviews. ${ }^{24-39}$ Typically these reactions employ a transition metal catalyst (most commonly an organometallic Ru or Ir complex) and a base to activate an alcohol by deprotonation and extraction of hydride from the $\alpha$-position. The unsaturated group thus formed can then go on to participate in the formation of new C-N and $\mathrm{C}-\mathrm{C}$ bonds. In this way a wide range of alcohols can act as the source of an alkyl group for alkylation, the most common substrates being amines or carbonyls. These methods avoid the use of activating leaving groups and halides, and do not lead to the formation of salt waste. In this way alkylated amines, carboxylic acids, amides and nitrogen containing heterocycles can be prepared.

The activation of 1,3-propanediol by hydrogen transfer and its use to prepare 1,3-diamino propanes by $N$-alkylation of secondary amines was demonstrated by Huh et al. employing $\mathrm{RuCl}_{3} \cdot \mathrm{nH}_{2} \mathrm{O}$ as the catalyst precursor in dioxane at $180{ }^{\circ} \mathrm{C} .{ }^{40}$ In boiling diglyme, quinolines result from the dehydrogenation initiated amination of 1,3-PDO in the presence of aniline catalysed by phosphine $\left(\mathrm{PBu}_{3}{ }_{3}\right)$ promoted ruthenium (III) chloride. ${ }^{41}$

An alternative procedure has been published by Madsen and co-workers ${ }^{42}$ including the addition of $\mathrm{MgBr}_{2} \cdot \mathrm{OEt}_{2}$ to the catalytic system as a promoter, and expanding the procedure to the synthesis of a range of functionalised quinoline derivatives. Treatment of napthylamines with 1,3-PDO in the presence of $\operatorname{IrCl}_{3} \cdot \mathrm{nH}_{2} \mathrm{O}$ promoted by BINAP enables $N$ heterocyclization in an analogous manor. ${ }^{43}$ Avoiding the dehydrogenation of the $N$ heterocyclized product, and therefore performing a dehydrative coupling, Achard and coworkers ${ }^{44}$ have prepared (functionalised) julolidines from tetrahydroquinolines and 1,3-PDO. Pentamethylcyclopentadienyl iridium(III) chloride dimer $\left[\mathrm{Cp}^{*} \mathrm{IrCl}_{2}\right]_{2}$ was employed as the 
catalyst precursor, promoted by diphenylphosphinobenzoic acid. The reaction was performed at $130{ }^{\circ} \mathrm{C}$ in toluene. $\mathrm{Cp} * \mathrm{Ir}(\mathrm{III})$ complexes have wide applicability in reactions that involve the removal and transfer of hydrogen to activate alcohols; in addition to the well established transfer amination protocols, ${ }^{25,30,33}$ many other organic hydrogen transfer and dehydrogenation reactions are possible, for example Oppenauer-type oxidation, ${ }^{45}$ dehydrogenation, ${ }^{29,36,46}$ the Guerbet reaction, ${ }^{47-49}$ and dynamic kinetic resolution. ${ }^{50-54}$

Previously Marr, Rebros and co-workers demonstrated that 1,3-PDO generated from the fermentation of crude glycerol from biodiesel can act as the substrate for the $\mathrm{N}$-alkylation of aniline. ${ }^{10}$ A Cp*Ir(III) $N$-heterocyclic carbene hydrogen transfer catalyst was employed in ionic liquid or toluene assisted by simple carbonate salts. When amination is operated in ionic liquid solvents, ${ }^{10,55}$ we previously noted ${ }^{23}$ that the substrate showed a tendency towards simultaneous dehydration. The resulting aldehydes can react together by aldol condensation and couple to yield C6 products. This cascade follows a similar mechanism to the Guerbet reaction. ${ }^{47,48}$ The potential importance of Guerbet chemistry in bio-renewable transformations has been underlined recently, as a method of transforming bio-ethanol to bio-butanol. ${ }^{56}$ The application of ionic liquid solvents and alteration of the concentration of amine were later shown to enable control over the reaction selectivity. ${ }^{23}$

Here is reported the use of a homogeneous hydrogen transfer catalyst to catalyse the dehydration of 1,3-propanediol in ionic liquid to propionaldehyde (propanal). This follows the report of amination by hydrogen transfer by coupled bio- and chemo-catalysis, ${ }^{10,23}$ and has the additional benefit of easier product separation. By assisting a dehydration reaction, the catalyst and ionic liquid remove oxygen from the bio-alcohol, and this reduces hydrogen bonding, rendering the organic products more volatile and easier to remove from the solvent. To the best of our knowledge, this is the first report on the selective transformation of 1,3PDO into propionaldehyde. The production of aldehydes is targeted due to their importance in chemical synthesis, ${ }^{57,58}$ being precursors for carboxylic acids and esters, olefins, amines, amides and higher aldehydes and alcohols. Hundreds of thousands of tonnes of propionaldehyde are prepared worldwide per year. The leading production method is the hydroformylation of ethene derived from petroleum. Bulk uses of propionaldehyde include the synthesis of trimethylolethane (and its derivatives) for the production of resins, coatings, plasticisers and lubricants. Propionaldehyde is also used extensively in the organic synthesis of fine chemicals. The high purity aldehydes required for pharmaceuticals, foods and fragrances are particularly valuable, and have higher market values than the parent alcohols. $\mathrm{Cp}^{*} \mathrm{IrCl}_{2}(\mathrm{NHC})\left(\mathrm{Cp}^{*}=\right.$ pentamethylcyclopentadienyl; $\mathrm{NHC}=$ carbene ligand $)$ complex $\mathbf{1}$ 
(See Figure 1) and base were applied to 1,3-PDO in ionic liquid; the major products observed were propionaldehyde (2), 2-methyl-pentenal (3), 2-methyl-pentanal (4), and 1-propanol (5) (See Scheme 1 (a)).

\section{Experimental}

1,3-Propanediol (98 \% w, Aldrich), $\mathrm{K}_{2} \mathrm{CO}_{3}(99.5 \% w, \mathrm{BDH}), \mathrm{KOH}(85 \% w$, Riedel-de Haen), $\mathrm{Cs}_{2} \mathrm{CO}_{3}$ (99.995 \% w, Sigma-Aldrich), propionaldehyde (97 \% w, Aldrich), 2-methyl2-pentenal (97\% w, Aldrich), 2-methyl-pentanal (> $95.0 \% \mathrm{w}, \mathrm{TCI})$, propanol (97\% $\mathrm{w}$, Sigma-Aldrich), $\mathrm{CH}_{3} \mathrm{OH}$ ( $\geq 99.9 \%$ w, CHROMASOLV, for HPLC, Sigma-Aldrich), $\mathrm{CDCl}_{3}$ (99\% w, Aldrich), $\mathrm{CD}_{3} \mathrm{C}(\mathrm{O}) \mathrm{CD}_{3}$ (VWR Chemicals), were used as received. 1, ${ }^{59} 1$-ethyl-2,3dimethyl-imidazolium- $N, N$-bistriflimide $\left(\right.$ EmmimNTf $\left._{2}\right),{ }^{60}$ and methyl-tri- $n$-octyl-ammonium$N, N$-bistriflimide $\left(\mathrm{N}_{1,8,8,8} \mathrm{NTf}_{2}\right)^{61}$ (Figure 1), were synthesized according to literature procedures. ${ }^{1} \mathrm{H}$ NMR spectra were run on $300 \mathrm{MHz}$ and $400 \mathrm{MHz}$ Bruker spectrophotometers. The chemical shifts are reported in ppm. Signal multiplicities are reported as singlet $(\mathrm{s})$, doublet $(\mathrm{d})$, triplet $(\mathrm{t})$, quartet (qrt), and multiplet $(\mathrm{m})(\mathrm{br}=$ broad). GC/MS spectroscopic data were collected on a MassHunter Workstation Software Qualitative Analysis - Version B.06.00 - Build 6.0.663.10 - Service Pack 1 - (C) Agilent Technologies, Inc. 2012. GC/MS column: Agilent Technologies, Inc.; 19091S-433UI; HP5MS UI; $30 \mathrm{~m} \mathrm{X} 0.250 \mathrm{~mm}$; 0.25 Micron; -60 to 325/350C; SN: USE137316H. GC/MS spectroscopic data were processed on MassHunter Data Analysis - MassHunter GC/MS Acquisition B.07.01.1805 - 12-Mar-2014 - (C) 1989-2014 Agilent Technologies.

\section{Hydrogen transfer initiated dehydration (HTID) of 1,3-propanediol (1,3-PDO) in} the presence of 1 and a base, in ionic liquid: screening reaction conditions.

1,3-PDO, 1, a base, and an ionic liquid (see Table S8) were added to a $50 \mathrm{~mL}$ round bottom flask connected, through a distillation condenser, to a $50 \mathrm{~mL}$ glass tube. The mixture was reacted at the selected temperature, at a controlled pressure of $c a .0 .35$ bar, for six hours, stirring at $1000 \mathrm{rpm}$. The reaction product, a colourless liquid, was isolated by distillation, being collected, for the duration of the six hours reaction, in the collecting glass tube kept at ca. $-196{ }^{\circ} \mathrm{C}\left(\mathrm{N}_{2}\right.$ (1) bath). After separation from the minor water layer, the crude product (see \% yield (based on propionaldehyde (2) in Table S8) was analysed by GC/MS (Table S18) and ${ }^{1} \mathrm{H}$ NMR (Table S27) spectroscopies. The reacted mixture, left in the $50 \mathrm{~mL}$ round bottom flask, was analysed by ${ }^{1} \mathrm{H}$ NMR spectroscopy. The crude product was distilled at 
atmospheric pressure, at $\mathrm{T} \cong 43{ }^{\circ} \mathrm{C}$, to yield $2 .{ }^{1} \mathrm{H} \mathrm{NMR}\left(\mathrm{CDCl}_{3}, 400 \mathrm{MHz}\right): \delta_{\mathrm{H}} 1.09\left(\mathrm{td}, J_{\mathrm{HH}}\right.$ $\left.=7.42, J_{\mathrm{HH}}=1.10 \mathrm{~Hz}, 3 \mathrm{H}\right), 2.45(\mathrm{~m}, 2 \mathrm{H}), 9.78(\mathrm{~m}, 1 \mathrm{H})$.

Detailed procedures for the recycling experiments are given in the supplementary data file.

\section{Analysis of reaction product solutions of HTID of 1,3-PDO in the presence of 1 and} a base, in ionic liquids: general methodology.

The amount of $\mathbf{5}$ in the isolated crude product was calculated via GC/MS spectroscopy. Integration of the ${ }^{1} \mathrm{H}$ NMR spectrum allowed calculation of the molar amounts of 2, 3 and 4, relative to 5. Combination of GC/MS and ${ }^{1} \mathrm{H}$ NMR spectroscopic information enabled calculation of the amount of $\mathbf{2}, \mathbf{3}$ and $\mathbf{4}$, in the isolated crude product.

The GC/MS and ${ }^{1} \mathrm{H}$ NMR analysis of reaction product solutions are described in the supplementary data file.

\section{Results and discussion}

Treatment of 1,3-PDO in ionic liquid solution with a base and a $\mathrm{Cp}^{*} \operatorname{IrCl}_{2}(\mathrm{NHC})$ complex has been found to lead to dehydration to yield aldehydes. ${ }^{23}$ The hydrogen transfer initiated dehydration (HTID) of 1,3-PDO was investigated in the presence of complex $\mathbf{1}$ and a base, in an ionic liquid as the solvent medium. The outcome of the reaction was explored in different ionic liquids, at different temperatures and pressures, and by varying the catalyst loading and the nature and loading of the base. Product solutions were analysed by a combination of ${ }^{1} \mathrm{H}$ NMR and GC/MS spectroscopies.

The ionic liquids reported (Figure 1) could be used to extract 1,3-propanadiol from fermentation broth, as they are hydrophobic due to the presence of the $\mathrm{NTf}_{2}$ anion, but they do not represent an optimized system for fermentation broth extraction. EmmimNTf 2 and $\mathrm{N}_{1,8,8,8} \mathrm{NTf}_{2}$ are examples of two very common classes of ionic liquid. An in depth study and optimization of the extraction is ongoing as part of the EU FP7 project GRAIL and many ionic liquids are being screened. At the same time the fermentation of glycerol to 1,3-PDO is being optimized and this is leading to an increase in the concentration of 1,3-propanediol that is achievable in solution, which has a direct effect on the ability to extract it efficiently. 
<smiles></smiles>

1<smiles>O=S(=O)(O)N(C(F)(F)F)S(=O)(=O)C(F)(F)F</smiles><smiles>CCn1cc[n+](C)c1C</smiles>

EmmimNTf $_{2}$

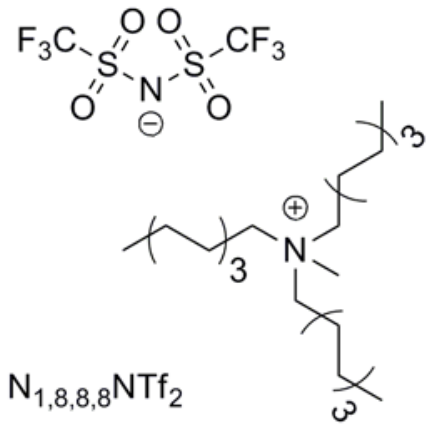

Figure 1. Structure of catalyst 1 and 1-ethyl-2,3-dimethyl-imidazolium- $N, N$-bistriflimide $\left(\right.$ EmmimNTf $\left._{2}\right)$ and methyl-tri-n-octyl-ammonium- $N, N$-bistriflimide $\left(\mathrm{N}_{1,8,8,8} \mathrm{NTf}_{2}\right)$, ionic liquids tested as the solvent media, in the $\mathrm{Cp}^{*} \operatorname{IrX}_{2}(\mathrm{NHC})$ catalysed HTID of 1,3-PDO.

The reaction was found to lead to a range of $\mathrm{C} 3$ and $\mathrm{C} 6$ alcohols and aldehydes: the major products observed were 2, 3, 4, and 5 (Scheme 1 (a)). The reaction outcome was found to be affected by the experimental conditions: reaction yield and selectivity could be controlled by tuning (a) the ionic liquid used as the solvent, the reaction (b) temperature and (c) pressure, (d) the loading of $\mathbf{1}$, and (e) the nature and loading of the base. The synthesis and isolation of 2 was first targeted.

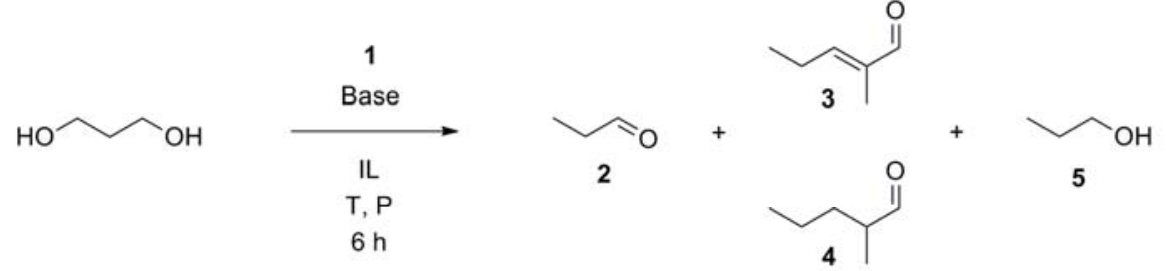

(a)

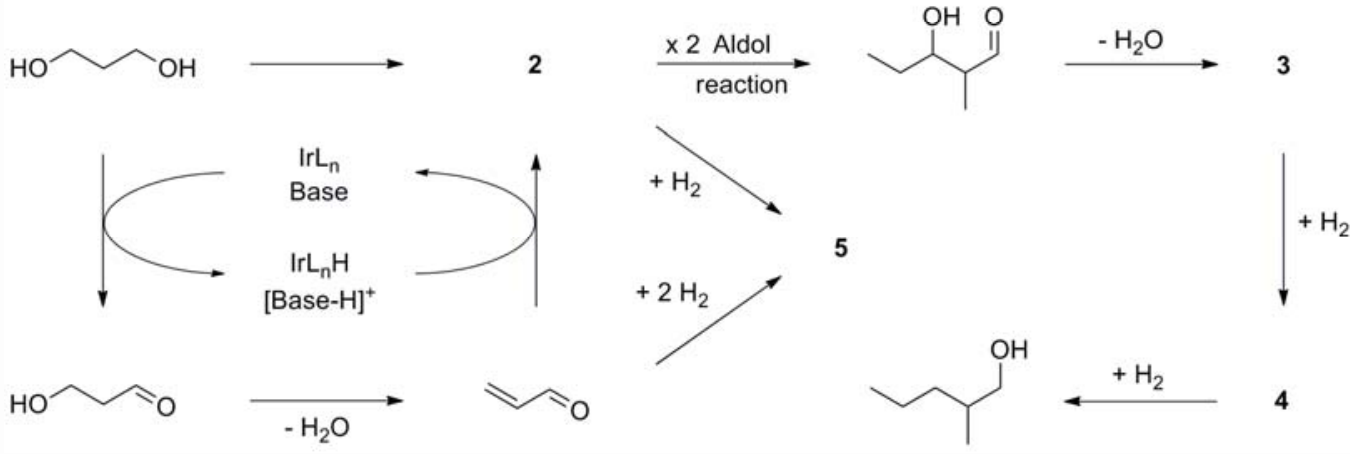

(b)

Scheme 1. HTID of 1,3-PDO catalysed by $\mathrm{Cp}^{*} \operatorname{IrX}_{2}(\mathrm{NHC})$ complex $\mathbf{1}$ in the presence of a base, in ionic liquids, at different temperatures and pressures: (a) major reaction products; (b) postulated reaction mechanism.

A postulated reaction sequence for the HTID of 1,3-PDO catalysed by $\mathrm{Cp}^{*} \operatorname{IrX} \mathrm{X}_{2}(\mathrm{NHC})$ complexes in the presence of a base, that rationalises the formation of the major products, is shown in Scheme 1 (b). HTID of 1,3-PDO allows formation of 2 via the intermediates 3- 
hydroxypropionaldehyde and acrolein. The formation of the dimer of acrolein was observed previously under similar conditions. ${ }^{23}$ Both 2 and acrolein could then undergo hydrogenation to 5. Furthermore, 2 can dimerise via the aldol reaction to yield, after dehydration, 3 . 3 can then undergo further hydrogenation to 4. Hydrogenation of the latter leads to 2-methylpentanol. In addition to the main reaction sequence, the intermediate 3hydroxypropionaldehyde could undergo a retro-aldol reaction to yield formaldehyde and acetaldehyde. Formaldehyde is a possible source of hydrogen, through dehydrogenation. Hydrogen can also be formed by dehydrogenation of alkyl chains to form olefins. The formation of traces of acetaldehyde and olefins are consistent with spectra obtained.

According to Scheme 1 (b) the formation of C6 products depends upon the aldol reaction of $\mathbf{2}$ in solution. The selectivity of the reaction should depend on the concentration of 2. Therefore the reaction outcome should be driven towards specific target compounds by tuning the reaction conditions. Running the HTID of 1,3-PDO in ionic liquids under conditions that allow the removal of 2 from the reaction mixture as soon as it is formed should minimise, the occurrence of the side-reactions leading to 3, 4 and 5. Conversely, higher selectivity towards these products should be favoured when allowing 2 to further react after its formation.

The HTID of 1,3-PDO was therefore successfully driven towards the selective production of 2 by reacting 1,3-PDO in the presence of the $\operatorname{Ir}(\mathrm{III})$ complex 1 ([1,3-PDO]:[Ir] =73.2 - 496.7; (see Table 1, Table 2, and tables $\mathrm{S} 1-\mathrm{S} 7$ ) and a base $\left(\mathrm{K}_{2} \mathrm{CO}_{3}\right.$, or $\mathrm{KOH}$, or $\mathrm{Cs}_{2} \mathrm{CO}_{3}$; [Base]:[1,3-PDO] $\left.=0.0302-0.2764\right)$, in ionic liquids EmmimNTf 2 , or $\mathrm{N}_{1,8,8,8} \mathrm{NTf}_{2}$, at temperature varying in the range $100-180^{\circ} \mathrm{C}$, and at a dynamic vacuum of ca. 0.35 bar. The vacuum allowed removal of the highly volatile 2 out of the reaction mixture as soon as it was formed; then, a low temperature trap allowed isolation of the crude product (see Figure S16) in high yield (up to $99 \%$ ), and highly rich in 2. 1,3-PDO was found to be completely consumed after six hours; the reaction outcome was then investigated after six hours. Selectivity towards 2 varied, depending on the reaction conditions, in the range $25.5-87.5$ $\%$. The rest $74.5-12.5 \%$ of product was found to be composed by 3,4 and 5, along with minor amounts of other side-products. Selectivity towards 3, 4 and 5 varied in the range 2.8 $61.2 \%, 0.0-17.5 \%, 3.3-56.7 \%$, respectively.

The ${ }^{1} \mathrm{H}$ NMR spectra of the isolated, crude product of HTID of 1,3-PDO at the above conditions (see Figure 2) display, in the aldehydic region, the triplet at $\delta_{\mathrm{H}} 9.78$ due to the aldehydic proton of the largely dominant species, 2, along with the doublet at $\delta_{\mathrm{H}} 9.60$ and the singlet at $\delta_{\mathrm{H}} 9.38$ corresponding to the aldehydic protons of $\mathbf{4}$ and $\mathbf{3}$, respectively; the triplet 
detected at $\delta_{\mathrm{H}} 3.59$ is due to the $\mathrm{CH}_{2} \mathrm{OH}$ protons of 5. Consistently, the GC/MS spectrum of the corresponding solutions (see Figure S1) displays the peaks due to 2, 3, 4 and 5.

EmmimNTf 2 and $\mathrm{N}_{1,8,8,8} \mathrm{NTf}_{2}$ are stable throughout the six hours reaction time: no decomposition of the ionic liquids was observed under any experimental conditions tested. The reacting mixtures were monitored by ${ }^{1} \mathrm{H}$ NMR spectroscopy: the resonances due to the protons of EmmimNTf $f_{2}$ and $\mathrm{N}_{1,8,8,8} \mathrm{NTf}_{2}$ remain unchanged throughout the reaction time (see Figure S4 and Figure S8, respectively).

The catalytic system is not sensitive to air, and the reaction is not affected by the presence of significant amounts of water (Table S7).

Mercury poisoning experiments showed the $\mathrm{Cp}$ * Ir systems to be homogeneous: 1 displayed virtually unperturbed activity in the presence of mercury, strongly suggesting genuine solution-phase catalysis (Table 2). ${ }^{62}$

The involvement of a monohydride iridium complex ${ }^{62,63}$ derivative of the catalytic precursor 1, as intermediate in the catalytic cycle ruling the base-assisted HTID of 1,3-PDO, is suggested by the ${ }^{1} \mathrm{H}$ NMR investigation of the reacting mixture: after running the HTID of 1,3-PDO, in the presence of 1 and $\mathrm{K}_{2} \mathrm{CO}_{3}$, in $\mathrm{N}_{1,8,8,8} \mathrm{NTf}_{2}$, at $150{ }^{\circ} \mathrm{C}$, for three hours, a sole singlet at $\delta_{\mathrm{H}}-16.54$ was observed in the hydride region (see Figure S14). In EmmimNTf along with the largely major singlet at $\delta_{\mathrm{H}}-16.57$, a minor peak at $\delta_{\mathrm{H}}-16.09$ is also observed (see Figure S15). The ${ }^{1} \mathrm{H}$ NMR resonance of the hydride (in $\mathrm{CDCl}_{3}$ ) lies in the expected range for terminal hydride complexes, by comparison with similar complexes reported previously. ${ }^{64-67}$ Further mechanistic work is required to comment on the role of such monohydride iridium complex in the catalytic cycle.

Complex 1 was monitored by ${ }^{1} \mathrm{H}$ NMR whilst running the HTID of 1,3-PDO in the presence of 1 and $\mathrm{K}_{2} \mathrm{CO}_{3}$, in $\mathrm{N}_{1,8,8,8} \mathrm{NTf}_{2}$, (analysis in EmmimNTf $\mathrm{f}_{2}$ was hampered by solventsignal overlap), at $\mathrm{T} 150{ }^{\circ} \mathrm{C}$, and at [1,3-PDO]:[Ir] $\cong 220.0$. The doublet at $\delta_{\mathrm{H}} 6.02\left(J_{\mathrm{HH}}=\right.$ $15.3 \mathrm{~Hz}$ ), due the methylenic protons of $\mathbf{1}$, was monitored during the course of the reaction. The catalyst precursor 1 was observed in the reaction mixture for $c a$. two hours since the reaction started. Several overlapping resonances were detected in the region $\delta_{\mathrm{H}} 5.00-7.00$ since the beginning of the reaction, preventing any further speculation regarding the nature of the active Ir complex formed in solution. The doublet at $\delta_{\mathrm{H}} 6.02$ was observed collapsing $c a$. three hours after starting the reaction. Further investigation will be carried out in order to understand the nature of the active catalytic Ir species. 


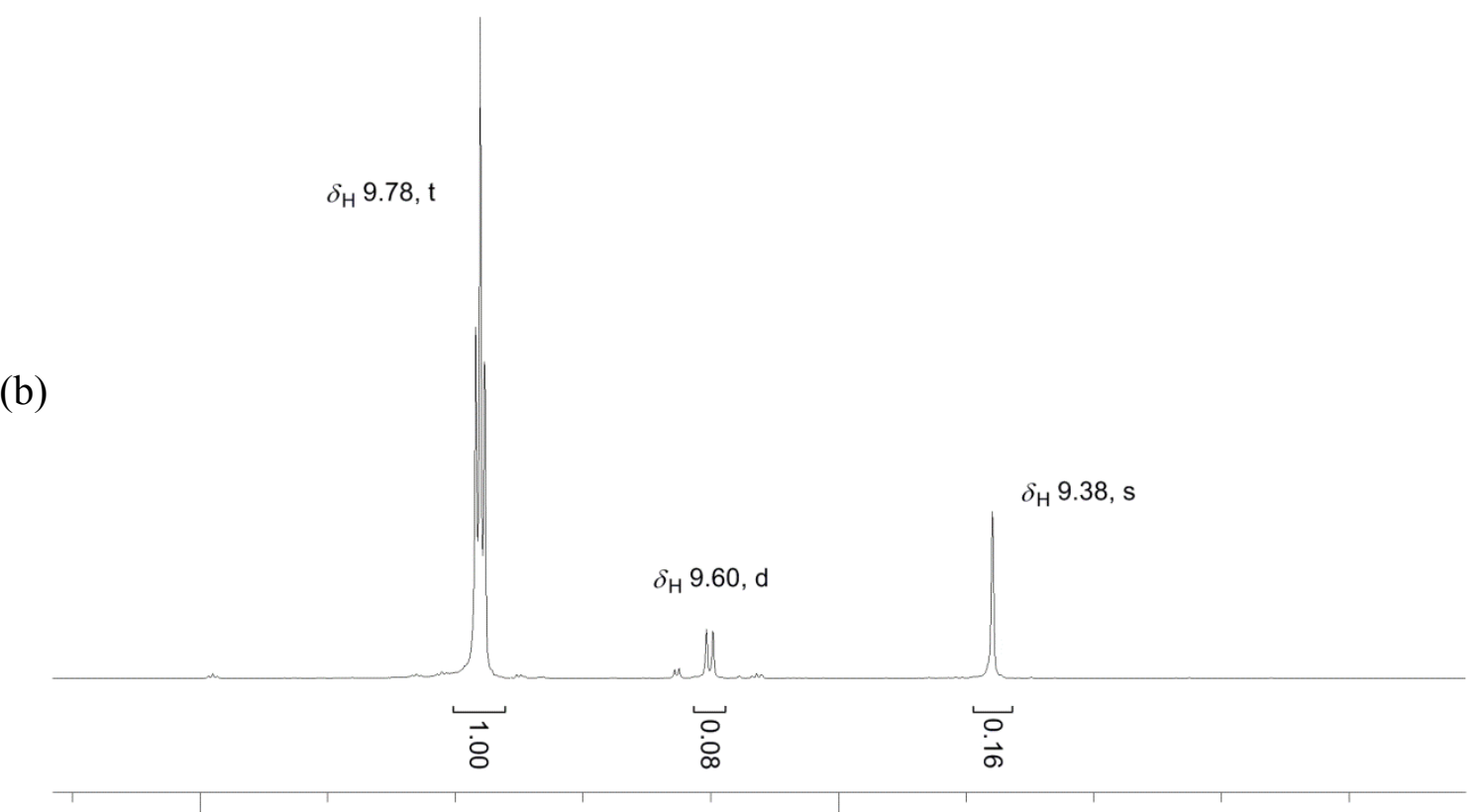

$\operatorname{ppm}(\mathrm{t} 1)^{10.00} \quad 9.50$

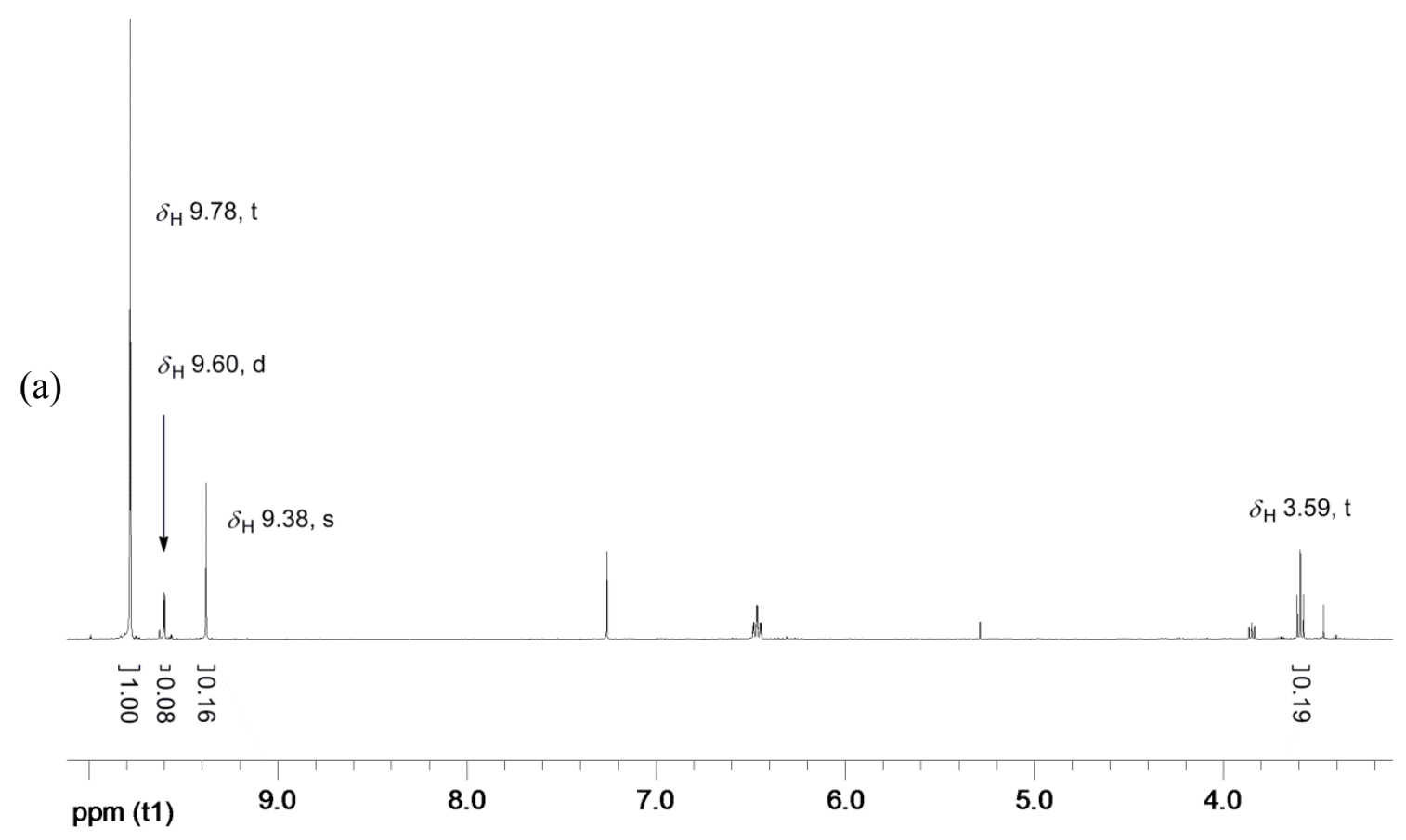

Figure 2. Example of a ${ }^{1} \mathrm{H}$ NMR spectrum of the isolated, crude product of HTID of 1,3-PDO in the presence of 1 and a base, in EmmimNTf ${ }_{2}$ or $\mathrm{N}_{1,8,8,8} \mathrm{NTf}_{2}$, at temperature varying in the range $100-180{ }^{\circ} \mathrm{C}$, and at a dynamic vacuum of $c a .0 .35$ bar: enlargement of the aldehydic and 1-propanol $\mathrm{CH}_{2} \mathrm{OH}$ region $\left(\delta_{\mathrm{H}} 3.10\right.$ - $\left.\delta_{\mathrm{H}} 10.10\right)(\mathrm{a})$; enlargement of the aldehydic region $\left(\delta_{\mathrm{H}} 9.00-\delta_{\mathrm{H}} 10.12\right)(\mathrm{b})$.

The non-volatility of the ionic liquid, along with the much lower boiling point of 2 (46.0 $\left.{ }^{\circ} \mathrm{C}\right)$ compared to that of the by-products $\left(3: 137.5{ }^{\circ} \mathrm{C} ; 4: 119.5{ }^{\circ} \mathrm{C} ; 5: 97.0^{\circ} \mathrm{C}\right)$ allowed then the facile separation of $\mathbf{2}$. The isolation of highly pure $\mathbf{2}$ was achieved via a mild distillation 
at $\mathrm{P}_{\mathrm{atm}}$ and $\mathrm{T}=43{ }^{\circ} \mathrm{C}$. The ${ }^{1} \mathrm{H}$ NMR spectrum of the distilled, isolated product (Figure S2) only displays resonances due to 2: a triplet at $\delta_{\mathrm{H}} 9.78$, a quartet of doublets at $\delta_{\mathrm{H}} 2.45$, and a triplet at $\delta_{\mathrm{H}} 1.10$. Consistently, only the peaks due to 2 are displayed in the GCMS spectrum of the distilled, isolated product (Figure S3). In conclusion, highly pure 2 was produced via HTID of 1,3-PDO, catalysed by $\mathbf{1}$ in the presence of a base, in ionic liquids, followed by a mild distillation. To the best of our knowledge, this is the first report on the selective transformation of 1,3-PDO into 2. 2 was only reported as a very minor component in the product mixture of dehydrogenation of $1,3-\mathrm{PDO}$, performed in several, extreme conditions. ${ }^{68-}$ 70

The influence of (a) the ionic liquid used as the solvent, (b) the catalyst loading, the reaction (c) temperature and (d) pressure, and (e) the nature and loading of the base on the selectivity towards the C3 and C6 aldehydes and alcohols and the yields of 2 was then investigated (see Table 1).

The catalyst 1 and the base are indispensable: in the absence of the iridium catalyst, 1,3PDO remains unreacted; also, no reaction of 1,3-PDO is observed when the HTID is carried out in the presence of 1 but in the absence of base (In Table 1: see entries 17 and 18, respectively).

The ionic liquids tested as the solvent media were EmmimNTf 2 and $\mathrm{N}_{1,8,8,8} \mathrm{NTf}_{2}$. The imidazolium cation is $\mathrm{C} 2$ protected with a methyl group to prevent side reactions involving deprotonation and the formation of carbenes. The ammonium ionic liquid was chosen as a cheaper alternative to the more common imidazolium ionic liquids. The bis(trifluoromethylsulfonyl)imide $\left(\mathrm{NTf}_{2}\right)$ anion confers hydrophobicity, ensuring the solvent forms two phases with water, and enabling a biphasic extraction of fermentation broth.

Yields and selectivities towards 2 are generally higher in EmmimNTf $f_{2}$ than $\mathrm{N}_{1,8,8,8} \mathrm{NTf}_{2}$ (Table 1: entries 3 and 23; 7 and 26; 9 and 25; 16 and 30). Although ionic liquids have been selected as solvents for the reaction primarily in order to enable a facile separation of the final, volatile products from the non-volatile solvent media (and also, prior to chemocatalysis, in the prospect of allowing extraction of 1,3-PDO from the aqueous glycerol fermentation broths), it was found that their use also affects the reaction outcome: while little effect on yields was observed, selectivity towards 2 was found to significantly improve in ionic liquids when compared to HTID of 1,3-PDO carried out in the absence of ionic liquid (Table 1: entries 7, 19, and 26). We have previously shown that ionic liquids support greater dehydration activity than toluene under related conditions. ${ }^{10,23}$ 
It is also worthy of note that when the HTID of 1,3-PDO was carried out in neat 1,3PDO, in molar concentrations corresponding to those of $\mathrm{N}_{1,8,8,8} \mathrm{NTf}_{2}$ (Table 1: entry 31) and EmmimNTf $_{2}$ solvents (Table 1: entry 32 ), the catalyst was found to turnover at a greater frequency. In these reactions the selectivity towards 2 was lower than for the optimised ionic liquid system.

The effect of catalyst loading on the yield of and selectivity towards 2 was investigated varying the ratio [1,3-PDO]:[Ir] in the range $c a .70 .0$ - ca. 500.0. While no significant effect on selectivity was observed, catalyst loading affects the yields of 2: the lower the ratio [1,3PDO]:[Ir], the higher the yield (Table 1: entries 5, 6, 7, and 8; 20 and 25; 21 and 26; 22, and 27). In both EmmimNTf $f_{2}$ and $\mathrm{N}_{1,8,8,8} \mathrm{NTf}_{2}$, only traces amount of 2 were observed to be formed when [1,3-PDO]:[Ir] > ca. 220.0.

Only a minor effect on the reaction outcome was observed when changing the base: yields and product distributions were similar when using either $\mathrm{K}_{2} \mathrm{CO}_{3}, \mathrm{KOH}$ or $\mathrm{Cs}_{2} \mathrm{CO}_{3}$ (Table 1: entries 7,12 , and $16 ; 26,28$, and 30 ). $\mathrm{K}_{2} \mathrm{CO}_{3}$ was then selected as the base for the HTID of 1,3-PDO catalysed by $\mathbf{1}$. Yields of and selectivity towards 2 were affected by the base molar concentration: the higher the base concentration the lower the yield of, and selectivity towards 2 (Table 1: entries 7, 14, and 15). This may suggest that the higher base concentration stimulates side-reactions, which could include dehydrogenation, retro-aldol, and orthometallation ${ }^{59}$ of $\mathbf{1}$. The HTID of 1,3-PDO was found to perform best when $\left[\mathrm{K}_{2} \mathrm{CO}_{3}\right]:[1,3-\mathrm{PDO}] \cong 0.0310$.

The effect of the reaction temperature has been explored in the range $80-180{ }^{\circ} \mathrm{C}$. Satisfying yields of and selectivity towards 2 were achieved at temperatures $120 \leq \mathrm{T} \leq 150$ ${ }^{\circ} \mathrm{C}$, in both EmmimNTf 2 and $\mathrm{N}_{1,8,8,8} \mathrm{NTf}_{2}$, and at a ratio [1,3-PDO]:[Ir] varying in the range ca. 70.0 - ca. 220.0. Minor conversions are observed at $\mathrm{T}<100{ }^{\circ} \mathrm{C}$ (Table 1: entries 4 and 24). In the range $100-150{ }^{\circ} \mathrm{C}$, the higher the temperature, the higher the yields of and selectivity towards 2, at any ratio [1,3-PDO]:[Ir] and in both EmmimNTf $_{2}$ and $\mathrm{N}_{1,8,8,8} \mathrm{NTf}_{2}$ (Table 1: entries $1,2,3$, and $4 ; 21,22,23$, and 24). Raising the temperature to $180{ }^{\circ} \mathrm{C}$ resulted in little improvement, and similar amounts of isolated 2 were formed (entries 7 and 9; 20 and 21): the ${ }^{1} \mathrm{H}$ NMR spectra of the isolated crude products show formation of further by-products containing alkenic protons, suggesting an increase in dehydrogenation activity. It is worth noting that selectivity towards 2 fails under $100{ }^{\circ} \mathrm{C}$ : selectivity towards 3 was found to increase up to $61.2 \%$ when running the HTID of 1,3 -PDO in $\mathrm{N}_{1,8,8,8} \mathrm{NTf}_{2}$ at $80{ }^{\circ} \mathrm{C}$, while selectivity towards 2 was $25.5 \%$ (Table 1 : entry 4 ). 
Table 1. HTID of 1,3-PDO in the presence of $\mathbf{1}$ and a base, in ionic liquids: yields ${ }^{\mathrm{a}}$ of $\mathbf{2}$, selectivity towards 2, 3, 4, and 5, and TOF.

\begin{tabular}{|c|c|c|c|c|c|c|c|c|c|c|c|c|}
\hline Entry & Solvent & Catalyst & [1,3-PDO]:[Ir] & Base & [Base]:[1,3-PDO] & $\mathrm{T}$ & $\%$ Yield $^{\mathrm{a}}(2)$ & 2 & 3 & 4 & 5 & $\operatorname{TOF}^{\mathrm{b}}\left[\mathrm{s}^{-1}\right]\left(\times 10^{3}\right)$ \\
\hline 1 & $\mathrm{~N}_{1,8,8,8} \mathrm{NTf}_{2}$ & 1 & 74.8 & $\mathrm{~K}_{2} \mathrm{CO}_{3}$ & 0.0310 & 150 & 84 & 85.9 & 5.9 & 1.5 & 6.7 & 2.90 \\
\hline 2 & $\mathrm{~N}_{1,8,8,8} \mathrm{NTf}_{2}$ & 1 & 73.2 & $\mathrm{~K}_{2} \mathrm{CO}_{3}$ & 0.0311 & 120 & 60 & 52.9 & 28.3 & 9.8 & 9.0 & 2.02 \\
\hline 3 & $\mathrm{~N}_{1,8,8,8}^{, 0,0} \mathrm{NTf}_{2}$ & 1 & 76.1 & $\mathrm{~K}_{2} \mathrm{CO}_{3}$ & 0.0302 & 100 & 27 & 70.4 & 12.1 & 13.1 & 4.4 & 0.96 \\
\hline 4 & $\mathrm{~N}_{1,8,8,8} \mathrm{NTf}_{2}$ & 1 & 75.6 & $\mathrm{~K}_{2} \mathrm{CO}_{3}$ & 0.0313 & 80 & 1 & 25.5 & 61.2 & 0.0 & 13.2 & 0.04 \\
\hline 5 & $\mathrm{~N}_{1,8,8,8} \mathrm{NTf}_{2}$ & 1 & 73.3 & $\mathrm{~K}_{2} \mathrm{CO}_{3}$ & 0.0308 & 150 & 84 & 75.2 & 10.4 & 5.1 & 9.3 & 2.83 \\
\hline 6 & $\mathrm{~N}_{1,8,8,8} \mathrm{NTf}_{2}$ & 1 & 98.9 & $\mathrm{~K}_{2} \mathrm{CO}_{3}$ & 0.0309 & 150 & 69 & 72.2 & 14.9 & 7.3 & 5.6 & 3.16 \\
\hline 7 & $\mathrm{~N}_{1,8,8,8} \mathrm{NTf}_{2}$ & 1 & 219.9 & $\mathrm{~K}_{2} \mathrm{CO}_{3}$ & 0.0303 & 150 & 51 & 76.2 & 11.8 & 6.4 & 5.5 & 5.23 \\
\hline 8 & $\mathrm{~N}_{1,8,8,8} \mathrm{NTf}_{2}$ & 1 & 496.7 & $\mathrm{~K}_{2} \mathrm{CO}_{3}$ & 0.0310 & 150 & 6 & 78.2 & 10.8 & 6.6 & 4.4 & 1.44 \\
\hline 9 & $\mathrm{~N}_{1,8,8,8} \mathrm{NTf}_{2}$ & 1 & 217.0 & $\mathrm{~K}_{2} \mathrm{CO}_{3}$ & 0.0316 & 180 & 49 & 82.0 & 7.1 & 4.2 & 6.8 & 4.96 \\
\hline 10 & $\mathrm{~N}_{1,8,8,8} \mathrm{NTf}_{2}$ & 1 & 73.6 & $\mathrm{KOH}$ & 0.0545 & 150 & 78 & 78.4 & 9.5 & 4.0 & 8.1 & 2.65 \\
\hline 11 & $\mathrm{~N}_{1,8,8,8} \mathrm{NTf}_{2}$ & 1 & 74.8 & $\mathrm{KOH}$ & 0.0536 & 100 & 11 & 73.0 & 8.8 & 9.9 & 8.3 & 0.39 \\
\hline 12 & $\mathrm{~N}_{1,8,8,8}^{1,0,0} \mathrm{NTf}_{2}$ & 1 & 218.7 & $\mathrm{KOH}$ & 0.0541 & 150 & 62 & 84.2 & 2.8 & 2.8 & 5.7 & 6.26 \\
\hline 13 & $\mathrm{~N}_{1,8,8,8} \mathrm{NTf}_{2}$ & 1 & 218.3 & $\mathrm{KOH}$ & 0.0496 & 100 & 2 & 39.3 & 4.1 & 0.0 & 56.7 & 0.18 \\
\hline 14 & $\mathrm{~N}_{1,8,8,8} \mathrm{NTf}_{2}$ & 1 & 219.8 & $\mathrm{~K}_{2} \mathrm{CO}_{3}$ & 0.1365 & 150 & 29 & 52.1 & 24.3 & 11.5 & 12.1 & 2.99 \\
\hline 15 & $\mathrm{~N}_{1,8,8,8} \mathrm{NTf}_{2}$ & 1 & 218.1 & $\mathrm{~K}_{2} \mathrm{CO}_{3}$ & 0.2764 & 150 & 20 & 54.1 & 22.4 & 12.8 & 10.6 & 2.07 \\
\hline 16 & $\mathrm{~N}_{1,8,8,8} \mathrm{NTf}_{2}$ & 1 & 207.3 & $\mathrm{CsCO}_{3}$ & 0.0321 & 150 & 17 & 78.1 & 10.8 & 2.6 & 8.5 & 1.58 \\
\hline 17 & $\mathrm{~N}_{1,8,8,8} \mathrm{NTf}_{2}$ & No catalyst & I & $\mathrm{K}_{2} \mathrm{CO}_{3}$ & 0.0312 & 150 & l & I & I & 1 & 1 & \\
\hline 18 & $\mathrm{~N}_{1,8,8,8}^{, 0,0} \mathrm{NTf}_{2}$ & 1 & 220.9 & No base & I & 150 & 1 & 1 & 1 & I & I & \\
\hline 19 & No IL & 1 & 226.6 & $\mathrm{~K}_{2} \mathrm{CO}_{3}$ & 0.0311 & 150 & 69 & 55.6 & 27.8 & 12.2 & 4.3 & 7.20 \\
\hline 20 & EmmimNTf $_{2}$ & 1 & 75.2 & $\mathrm{~K}_{2} \mathrm{CO}_{3}$ & 0.0309 & 180 & 85 & 72.5 & 12.5 & 3.7 & 11.3 & 2.97 \\
\hline 21 & EmmimNTf $_{2}$ & 1 & 75.1 & $\mathrm{~K}_{2} \mathrm{CO}_{3}$ & 0.0315 & 150 & 78 & 73.0 & 10.1 & 8.6 & 8.3 & 2.72 \\
\hline 22 & $\mathrm{EmmimNTf}_{2}$ & 1 & 75.6 & $\mathrm{~K}_{2} \mathrm{CO}_{3}$ & 0.0307 & 120 & 74 & 73.3 & 13.9 & 7.4 & 5.3 & 2.60 \\
\hline 23 & $\mathrm{EmmimNTf}_{2}$ & 1 & 74.7 & $\mathrm{~K}_{2} \mathrm{CO}_{3}$ & 0.0311 & 100 & 60 & 69.2 & 7.2 & 17.5 & 6.1 & 2.09 \\
\hline 24 & EmmimNTf $_{2}$ & 1 & 74.8 & $\mathrm{~K}_{2} \mathrm{CO}_{3}$ & 0.0312 & 80 & 1 & 67.3 & 3.5 & 25.0 & 4.2 & 0.04 \\
\hline 25 & EmmimNTf $_{2}$ & 1 & 221.9 & $\mathrm{~K}_{2} \mathrm{CO}_{3}$ & 0.0314 & 180 & 62 & 77.1 & 10.6 & 3.9 & 8.4 & 6.35 \\
\hline 26 & EmmimNTf $_{2}$ & 1 & 219.7 & $\mathrm{~K}_{2} \mathrm{CO}_{3}$ & 0.0315 & 150 & 70 & 72.7 & 12.5 & 6.1 & 8.6 & 7.07 \\
\hline 27 & $\mathrm{EmmimNTf}_{2}$ & 1 & 225.8 & $\mathrm{~K}_{2} \mathrm{CO}_{3}$ & 0.0304 & 120 & 51 & $80.3^{\mathrm{c}}$ & $8.0^{\mathrm{c}}$ & $9.6^{\mathrm{c}}$ & $2.0^{\mathrm{c}}$ & 5.33 \\
\hline 28 & EmmimNTf $_{2}$ & 1 & 226.1 & $\mathrm{KOH}$ & 0.0555 & 150 & 54 & 85.2 & 5.9 & 1.4 & 7.5 & 5.68 \\
\hline 29 & $\mathrm{EmmimNTf}_{2}$ & 1 & 74.5 & $\mathrm{KOH}$ & 0.0540 & 80 & 1 & 37.3 & 5.8 & 41.5 & 15.4 & 0.04 \\
\hline 30 & EmmimNTf $_{2}$ & 1 & 220.2 & $\mathrm{CsCO}_{3}$ & 0.0313 & 150 & 67 & 82.9 & 5.7 & 2.8 & 8.6 & 6.85 \\
\hline 31 & 1,3-PDO & 1 & 350.9 & $\mathrm{~K}_{2} \mathrm{CO}_{3}$ & 0.0068 & 150 & $-{ }^{d}$ & 61.2 & 24.3 & 10.3 & 4.1 & $10.28^{\mathrm{d}}$ \\
\hline 32 & 1,3-PDO & 1 & 203.2 & $\mathrm{~K}_{2} \mathrm{CO}_{3}$ & 0.0118 & 150 & $-{ }^{\mathrm{d}}$ & 66.3 & 18.3 & 9.0 & 6.5 & $7.03^{\mathrm{d}}$ \\
\hline
\end{tabular}

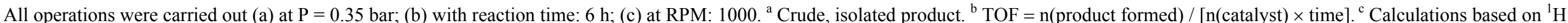
NMR (See Table S18, entry 27). ${ }^{d}$ In entries 31 and 32, 1,3-PDO was used as both the substrate and the solvent. 
The recyclability of the catalytic system generated by precursor 1 towards the HTID of 1,3-PDO was investigated in both EmmimNTf $f_{2}$ and $\mathrm{N}_{1,8,8,8} \mathrm{NTf}_{2}$. In the presence of $\mathrm{K}_{2} \mathrm{CO}_{3}$, at 120 and $150{ }^{\circ} \mathrm{C}$ and 0.35 bar, at catalyst loading [1,3-PDO]:[Ir] $\cong 75.0$ and 220.0, 1 was found to be a highly recyclable catalyst precursor. The base was found to be unstable and further aliquots of base were required to attain good recycling. Reloading only with $\mathbf{1}$, in the absence of additional base, the catalyst activity collapsed almost entirely after the first cycle when testing the recyclability in $\mathrm{N}_{1,8,8,8} \mathrm{NTf}_{2}$, at $150{ }^{\circ} \mathrm{C}$ and 0.35 bar, at catalyst loading [1,3PDO]:[Ir] $\cong 75.0$. In EmmimNTf 2 , under the same conditions, still reloading only with 1, the crude product yield fell from $78 \%$ to $54 \%$ and then $29 \%$ from the first to the second and then third cycle, respectively, showing significant, quick decrease in catalyst activity.

In EmmimNTf 2 , the catalyst was found to be recyclable for at least 10 catalytic runs at $150{ }^{\circ} \mathrm{C}$ and at catalyst loading [1,3-PDO]:[Ir] $\cong 75.0$. No significant loss of activity or selectivity towards 2 was observed (Figure 3, and Table S1): the percentage yield of crude 2 varied in the range $75-99 \%\left(1^{\text {st }}\right.$ catalytic run: $82 \% ; 10^{\text {th }}$ catalytic run: $75 \%$ ) (Figure 3 (a)); the selectivity towards 2 varied in the range $65.3-71.7 \%$ (Figure 3 (b)).

Yield $^{\mathrm{a}}$

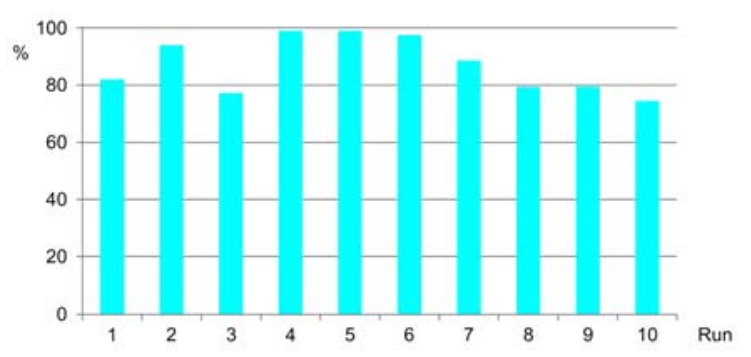

(a)

\section{Selectivity}
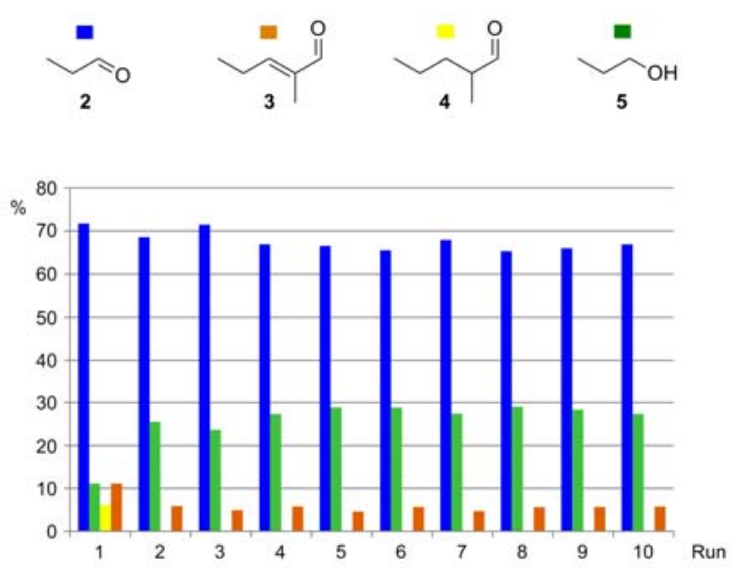

(b)

Figure 3. Recycling 1 as catalyst precursor towards HTID of 1,3-PDO ([1,3-PDO]:[Ir] $\cong 75.0)$ in EmmimNTf $_{2}$, in the presence of $\mathrm{K}_{2} \mathrm{CO}_{3}$, at $150{ }^{\circ} \mathrm{C}$ and 0.35 bar: (a) yield of crude 2; (b) selectivity towards $2,3,4$, and $5 .{ }^{\mathrm{a}}$ Crude, isolated product.

The recyclability of $\mathbf{1}$, proven to be effective over the 10 catalytic runs at $150{ }^{\circ} \mathrm{C}$ and [1,3-PDO]:[Ir] $\cong 75.0$, was then tested, and successfully confirmed, at different temperatures and catalyst loadings, over 5 catalytic runs. At $150{ }^{\circ} \mathrm{C}$ and [1,3-PDO]:[Ir] $\cong 220.0$ (Table S2), very little changes in the percentage yields of crude 2 were observed over the 5 catalytic runs 
$\left(1^{\text {st }}\right.$ catalytic run: $73 \% ; 5^{\text {th }}$ catalytic run: $74 \%$ ) (Figure $\left.4(\mathrm{a})\right)$. Also, the reaction remained highly selective towards 2 ( $\%$ of $2: 1^{\text {st }}$ catalytic run, $77.6 \% ; 5^{\text {th }}$ catalytic run, $76.2 \%$ ) (Figure 4 (b)). When testing the recyclability of 1 at $120{ }^{\circ} \mathrm{C}$ and [1,3-PDO]:[Ir] $\cong 75.0$ over 5 catalytic runs (Table S3), the percentage yields of crude 2 varied in the range $72-79 \%\left(1^{\text {st }}\right.$ catalytic run: $72 \%$; $5^{\text {th }}$ catalytic run: $78 \%$ ) (Figure 5 (a)), while the selectivity towards 2 varied in the range $71.2-76.2 \%$ (Figure 5 (b)).

The ionic liquid EmmimNTf $\mathrm{E}_{2}$ is stable throughout the 10 and 5 recycling runs, at any of the above experimental conditions: the ${ }^{1} \mathrm{H}$ NMR spectrum of the $\mathrm{CDCl}_{3}$ solutions of the reacting mixture after the six hours reaction shows that the triplet at $\delta_{\mathrm{H}} 1.51$ and the singlets at 2.64, and 3.83, due to the methylic protons, the quartet at $\delta_{\mathrm{H}} 4.14$, due to the methylenic protons, and the singlet at $\delta_{\mathrm{H}} 7.19$, due to the alkenic protons of EmmimNTf ${ }_{2}$, remain unchanged throughout the reaction time of each of the 10 and 5 recycling runs (see Figure S4). 
Yield $^{\mathrm{a}}$

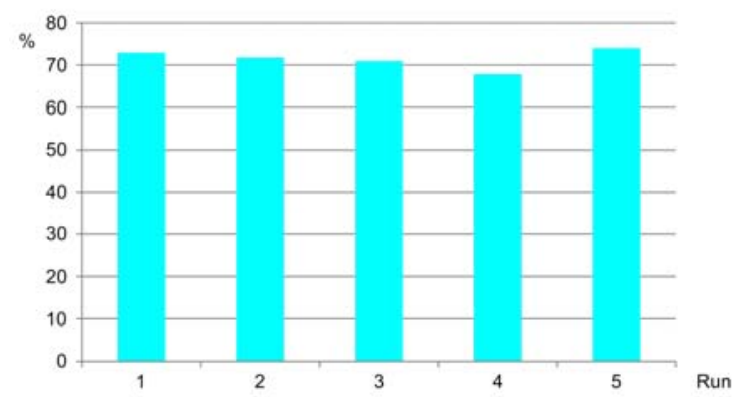

(a)
Selectivity
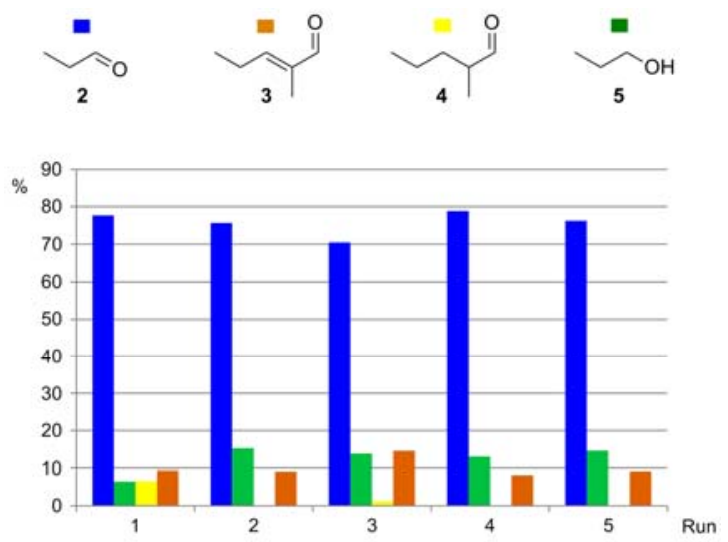

(b)

Figure 4. Recycling 1 as catalyst precursor towards HTID of 1,3-PDO ([1,3-PDO]:[Ir] $\cong 220.0)$ in EmmimNTf Emm $_{2}$ in the presence of $\mathrm{K}_{2} \mathrm{CO}_{3}$, at $150{ }^{\circ} \mathrm{C}$ and 0.35 bar: (a) yield of crude 2; (b) selectivity towards 2, 3, 4, and 5. ${ }^{\mathrm{a}}$ Crude, isolated product.

Yield $^{\mathrm{a}}$

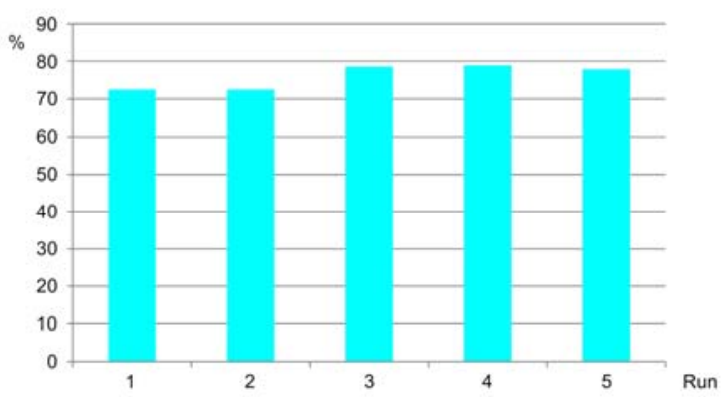

(a)
Selectivity
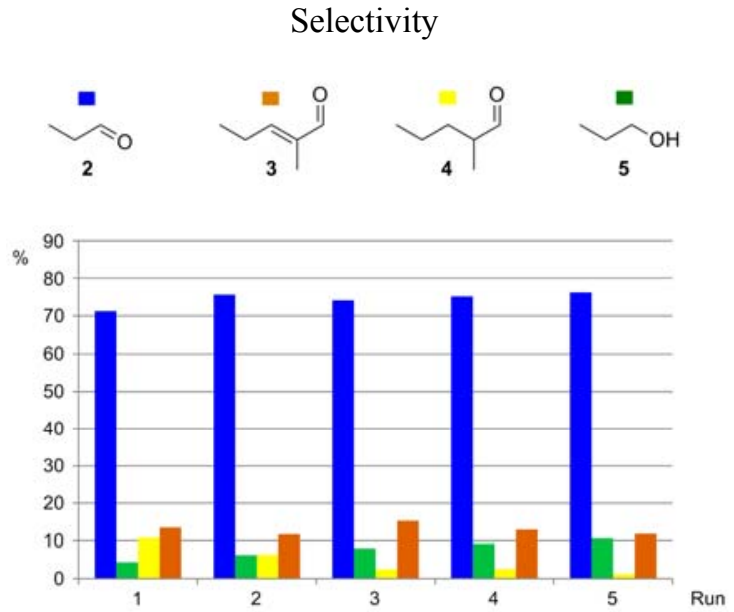

(b)

Figure 5. Recycling 1 as catalyst precursor towards HTID of 1,3-PDO ([1,3-PDO]:[Ir] $\cong 75.0)$ in $\operatorname{EmmimNTf}_{2}$, in the presence of $\mathrm{K}_{2} \mathrm{CO}_{3}$, at $120^{\circ} \mathrm{C}$ and 0.35 bar: (a) yield of crude 2; (b) selectivity towards 2, 3, 4, and 5. ${ }^{\mathrm{a}}$ Crude, isolated product. 
$\mathbf{1}$ is recyclable also in $\mathrm{N}_{1,8,8,8} \mathrm{NTf}_{2}$. High selectivity towards 2 was observed over the 10 catalytic runs when testing the catalyst recycling at $150^{\circ} \mathrm{C}$ and $[1,3-\mathrm{PDO}]:[\mathrm{Ir}] \cong 75.0(\%$ of 2 : $1^{\text {st }}$ catalytic run, $83.9 \% ; 10^{\text {th }}$ catalytic run, $73.4 \%$ ) (Table S6 and Figure S7 (b)), and over the 5 catalytic runs at $150{ }^{\circ} \mathrm{C}$ and $[1,3-\mathrm{PDO}]:[\operatorname{Ir}] \cong 220.0\left(\%\right.$ of $2: 1^{\text {st }}$ catalytic run, $87.5 \% ; 5^{\text {th }}$ catalytic run, $82.2 \%$ ) (Table S4 and Figure S5 (b)) and at $120{ }^{\circ} \mathrm{C}$ and [1,3-PDO]:[Ir] $\cong 75.0$ ( $\%$ of $2: 1^{\text {st }}$ catalytic run, $81.3 \% ; 5^{\text {th }}$ catalytic run, $76.0 \%$ ) (Table S5 and Figure S6 (b)).

At $150{ }^{\circ} \mathrm{C}$ and [1,3-PDO]:[Ir] $\cong 220.0$, the percentage yield of crude 2 was found to be $60 \%$ in the $1^{\text {st }}$ run and $57 \%$ in the $5^{\text {th }}$ run, with maximum and minimum values of $62 \%\left(3^{\text {rd }}\right.$ run) and $48 \%\left(2^{\text {nd }}\right.$ run), respectively (Figure S5 (a)). At $120{ }^{\circ} \mathrm{C}$ and $[1,3-\mathrm{PDO}]:[\mathrm{Ir}] \cong 75.0$, the percentage yield of crude 2 varied in the range $44-67 \%$, and was found almost identical in the $1^{\text {st }}(59 \%)$ and $5^{\text {th }}$ run (60\%) (Figure S6 (a)). More fluctuation in the percentage yields of crude 2 was observed over the 10 catalytic runs when testing the recyclability of $\mathbf{1}$ at 150 ${ }^{\circ} \mathrm{C}$ and at [1,3-PDO]:[Ir] $\cong 75.0$ in $\mathrm{N}_{1,8,8,8} \mathrm{NTf}_{2}$ (Figure $\mathrm{S} 7$ (a)), when compared to EmmimNTf 2 . The percentage yield of crude 2, after dropping from $86 \%$ ( $1^{\text {st }}$ run) to $22 \%$ $\left(2^{\text {nd }}\right.$ run), was found to vary in the range $54-77 \%$ from the $3^{\text {rd }}$ to the $10^{\text {th }}$ catalytic run $\left(3^{\text {rd }}\right.$ catalytic run: $54 \% ; 10^{\text {th }}$ catalytic run: $58 \%$ ).

The ionic liquid $\mathrm{N}_{1,8,8,8} \mathrm{NTf}_{2}$ is also stable throughout the 10 and 5 recycling runs, at any of the above experimental conditions: the ${ }^{1} \mathrm{H}$ NMR spectra of the $\mathrm{CDCl}_{3}$ solutions of the reacting mixture after the six hours reaction show that the triplet at $\delta_{\mathrm{H}} 0.88$ due to the $\mathrm{CH}_{2} \mathrm{CH}_{3}$ methylic protons, the broad multiplets at $\delta_{\mathrm{H}} 1.31$ and 1.64 due to the $-\mathrm{CCH}_{2} \mathrm{C}$ methylenic protons, the singlet at 3.01 due to the $-\mathrm{NCH}_{3}$ methylic protons, and the multiplet at $\delta_{\mathrm{H}} 3.18$ due to the $-\mathrm{NCH}_{2}$ - methylenic protons of $\mathrm{N}_{1,8,8,8} \mathrm{NTf}_{2}$, remain unchanged during the course of the reaction for each of the 10 and 5 recycling runs (Figure S8). 


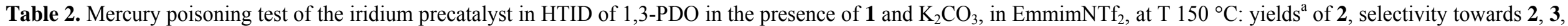
$\mathbf{4}$, and $\mathbf{5}$, and TOF.

\begin{tabular}{|c|c|c|c|c|c|c|c|}
\hline [1,3-PDO]:[Ir] & [Base]:[1,3-PDO] & \% Yield ${ }^{\mathrm{a}}(2)$ & 2 & 3 & 4 & 5 & $\operatorname{TOF}^{\mathrm{b}}\left[\mathrm{s}^{-1}\right]\left(\times 10^{3}\right)$ \\
\hline 206.3 & 0.0312 & 77 & 78.0 & 9.4 & 6.6 & 6.0 & 7.32 \\
\hline
\end{tabular}

The reaction was carried out (a) at $\mathrm{P}=0.35$ bar; (b) with reaction time: $6 \mathrm{~h}$; (c) at RPM: 1000. ${ }^{\mathrm{a} C r u d e}$, isolated product. ${ }^{\mathrm{b}} \mathrm{TOF}=\mathrm{n}($ product formed) $/[\mathrm{n}(\mathrm{catalyst}) \times$ time] . 
Further investigation of the HTID of 1,3-PDO will be aimed at targeting other valueadded chemicals. The reaction parameters will be tuned in order to drive the reaction outcome selectively towards the other products. Allowing propionaldehyde to further react after its formation should increase the percentage of $\mathrm{C} 6$ aldehydes, compared to propionaldehyde, in the reaction mixture. Amongst them, 2-methyl-pentenal is a valuable chemical. $^{58}$

\section{Conclusions.}

We have shown that complex 1 forms a highly recyclable catalyst for the selective production of a range of $\mathrm{C} 3$ and $\mathrm{C} 6$ aldehydes via homogeneous HTID of 1,3-PDO in ionic liquids. The successful isolation of highly pure propionaldehyde can be easily achieved under reduced pressure, and distillation, with minimal waste. In addition HTID of 1,3-PDO in ionic liquids is successful also when significant volumes of water are involved in the reaction, and in the presence of air. The successful synthesis and isolation of value-added chemicals out of the ionic liquid solutions of 1,3-PDO (mimicking the product of extraction of aqueous glycerol fermentation broth) proves that the combination of $\mathrm{Cp}^{*} \operatorname{IrX} \mathrm{X}_{2}(\mathrm{NHC})$ catalysed HTID of 1,3-PDO in ionic liquids with bio-catalysis has, ultimately, the potential to allow the transformation of waste glycerol into valuable chemicals that can be simply isolated. This valorisation of waste to chemicals would add significant value and improve the economics of biomass waste utilization.

\section{Acknowledgements}

This work was supported by GRAIL (Grant agreement no: 613667), project co-financed by the European Commission under the $7^{\text {th }}$ Framework Programme. The assistance provided by Queen's University Ionic Liquid Laboratories (QUILL), and the analytical chemistry service (ASEP) and glassblowing service at Queen's University Belfast, is acknowledged.

\section{Notes and references}

1. U.S. Department of Energy (2004) Top Value Added Chemicals from Biomass (Vol. 1) (Ed's T. Werpy and G. Petersen), Pacific Northwest National Laboratory (PNNL), National Renewable Energy Laboratory (NREL),Office of Biomass Program (EERE). http://www.eere.energy.gov/.

2. T. Banner, A. Fosmer, H. Jessen, E. Marasco, B. Rush, J. Veldhouse and M. De Souza, "Biocatalysis for Green Chemistry and Chemical Process Development," ed's J. Tao and R. Kazlauskas, Wiley, New Jersey, 2011, 429-467.

3. A. C. Marr and S. F. Liu, Trends Biotech., 2011, 29, 199-204.

4. US6013494, Jan 11 2000, C. E. Nakamura, A. A. Gatenby, A. Kuang-Hua Hsu, R. D. La Reau, S. L. Haynie, M. Diaz-Torres, D. E. Trimbur, G. M. Whited, V. Nagarajan, M. S. Payne, S. K. Picataggio, R. V. Nair, 
"Method for the production of 1,3-propanediol by recombinant microorganisms", A, E. I. Du Pont De Nemours And Company, Genencor International.

5. C.S. Lee, M.K. Aroua, W.M.A.W. Daud, P. Cognet, Y. Pérès-Lucchese, P-L Fabre, O. Reynes, and L. Latapie, Renew. Sust. Energ. Rev. 2015, 42, 963-972.

6. P. Kubiak, K. Leja, K. Myszka, E. Celinska, M. Spychała, D. Szymanowska-Powałowska, K. Czaczyk, and W. Grajek, Process Biochem., 2012, 47, 1308-1319.

7. R.K. Saxena, P. Anand, S. Saran, and J. Isar, Biotechnol. Adv., 2009, 27, 895-913.

8. M. A. Ricci, A. Russo, I. Pisano, L. Palmieri, M. de Angelis, and G. Agrimi, J. Microbiol. Biotechnol. 2015, 25, 893-902.

9. C. E. Nakamura and G. M. Whited, Curr. Opin. Biotech. 2003, 14, 454-459.

10. S. F. Liu, M. Rebros, G. Stephens and A. C. Marr, Chem. Commun, 2009, 2308-2310.

11. E. Wilkens, A. K. Ringel, D. Hortig, T. Willke, and K.-D. Vorlop, Appl. Microbiol. Biotechnol., 2012, 93, 1057-1063.

12. D. Dietz and A.-P. Zeng, Bioprocess Biosyst. Eng., 2014, 37, 225-233.

13. R. Dobson, V. Gray, K. Rumbold, J. Ind. Microbiol. Biotechnol., 2012, 39, 217-226.

14. P. Bonhôte, A-P Dias, M. Armand, N. Papageorgiou, K. Kalyanasundaram and M. Grätzel, Inorg. Chem., 1996, 35, 1168-1178.

15. M. Stoffers and A. Górak, Sep. Purif. Technol. 2013, 120, 415-422.

16. D. Rabari and T. Banerjee, Ind. Eng. Chem. Res., 2014, 53, 18935-18942.

17. K. E. Gutowski, G. A. Broker, H. D. Willauer, J.G. Huddleston, R. P. Swatloski, J. D. Holbrey, and R. D. Rogers, J. Am. Chem. Soc., 2003, 125, 6632-6633.

18. J.-Y. Dai, Y.-Q. Sun, and Z.-L. Xiu, Eng. Life Sci. 2014, 14, 108-117.

19. M.G. Freire, A. F. Cláudio, J. M. Araújo, J. A. Coutinho, I. M. Marrucho, J. N. Canongia Lopes, and L. P. Rebelo, Chem. Soc. Rev. 2012, 41, 4966-4995.

20. A. Müller, and A. Górak, Sep. Purif. Technol. 2012, 97, 130-136.

21. A. Müller, R. Schulz, J. Wittmann, I. Kaplanow, and A. Górak, RSC Advances, 2013, 3, 148-156.

22. M. Matsumoto, K. Nagai, and K. Kondo, Solvent Extr. Res. Dev., 2015, 22, 209-213.

23. S. D. Lacroix, A. Pennycook, S. Liu, T. T. Eisenhart and A. C. Marr, Catal. Sci. Technol., 2012, 2, 288-290.

24. A. C. Marr, Catal. Sci. Technol., 2012, 2, 279-287.

25. M. Pera-Titus, and F. Shi, ChemSusChem, 2014, 7, 720-722.

26. M. Haniti, S. A. Hamid, P. A. Slatford, and J. M. J. Williams, Adv. Synth. Catal. 2007, 349, 1555-1575.

27. G. Guillena, D. J. Ramón, and M. Yus, Angew. Chem. Int. Ed. 2007, 46, 2358-2364.

28. T. D. Nixon, M. K. Whittlesey, and J. M. J. Williams, Dalton Trans., 2009, 753-762.

29. G. E. Dobereiner, and R. H. Crabtree, Chem. Rev. 2010, 110, 681-703.

30. G. Guillena, D. J. Ramón, and M. Yus, Chem. Rev. 2010, 110, 1611-1641.

31. A. J. A. Watson and J. M. J. Williams, 2010, Science, 2010, 329, 635-636.

32. O. Saidi, and J. M. J. Williams, Top. Organomet. Chem. 2011, 34, 77-106.

33. S. Bähn, S. Imm, L. Neubert, M. Zhang, H. Neumann, and M. Beller, ChemCatChem, 2011, 3, 1853-1864.

34. Y. Obora, and Y. Ishii, Synlett, 2011, 30-51.

35. S. Pan, and T. Shibata, ACS Catal., 2013, 3, 704-712.

36. C. Gunanathan and D. Milstein, Science, 2013, 341, 1229712.

37. J. Schranck, A. Tlili, and M. Beller, Angew. Chem. Int. Ed. 2013, 52, $7642-7644$.

38. Y. Obora, ACS Catal., 2014, 4, 3972-3981.

39. M. Pera-Titus and F. Shi, ChemSusChem, 2014, 7, 720-722.

40. K.-T. Huh, S. C. Shim, and C. H. Doh, Bull. Korean Chem. Soc., 1990, 11, 45-49.

41. Y. Tsuji, K.-T. Huh, and Y. Watanabe, J. Org. Chem., 1987, 52, 1673-1680.

42. R. N. Monrad, and R. Madsen, Org. Biomol. Chem., 2011, 9, 610-615.

43. H. Aramoto, Y. Obora, and Y. Ishii, J. Org. Chem., 2009, 74, 628-633.

44. A. Labed, F. Jiang, I. Labed, A. Lator, M. Peters, M. Achard, A. Kabouche, Z. Kabouche, G. V. M. Sharma, and C. Bruneau, ChemCatChem, 2015, 7, 1090-1096.

45. F. Hanasaka, K. Fujita and R. Yamaguchi, Organometallics, 2004, 23, 1490-1492.

46. J. Wu, D. Talwar, S. Johnston, M. Yan, and J-L. Xiao, Angew. Chem. Int. Ed. 2013, 52, 6983 -6987.

47. M. Guerbet, C. R. Acad. Sci., 1899, 128, 1002-1004.

48. M. Guerbet, C. R. Acad. Sci., 1909, 149, 129-132. 
49. T. Matsu-ura, S. Sakaguchi, Y. Obora, and Y. Ishii, J. Org. Chem. 2006, 71, 8306-8308.

50. A. C. Marr, C. L. Pollock and G. C. Saunders, Organometallics, 2007, 26, 3283-3285.

51. R. Corberán and E. Peris, Organometallics, 2008, 27, 1954-1958.

52. T. Jerphagnon, R. Haak, F. Berthiol, A. J. A. Gayet, V. Ritleng, A. Holuigue, N. Pannetier, M. Pfeffer, A. Voelklin, L. Lefort, G. Verzijl, C. Tarabiono, D. B. Janssen, A. J. Minnaard, B. L. Feringa, and J. G. de Vries, Top. Catal., 2010, 53, 1002-1008.

53. C. L. Pollock, K. J. Fox, S. D. Lacroix, J. McDonagh, P. C. Marr, A. M. Nethercott, A. Pennycook, S. Qian, L. Robinson, G. C. Saunders, and A. C. Marr, Dalton Trans., 2012, 41, 13423-13428.

54. J. G. de Vries, Top. Catal. 2014, 57, 1306-1317.

55. O. Saidi, A. J. Blacker, G. W. Lamb, S. P. Marsden, J. E. Taylor, and J. M. J. Williams, Org. Process Res. Dev., 2010, 14, 1046-1049.

56. G. R. M. Dowson, M. F. Haddow, J. Lee, R. L. Wingad, and D. F. Wass, Angew. Chem. Int. Ed. 2013, 52, 9005-9008.

57. R. Franke, D. Selent, and A. Börner, Chem. Rev. 2012, 112, 5675-5732.

58. J. G. Stevens, R. A. Bourne, and M. Poliakoff, Green Chem., 2009, 11, 409-416.

59. R. Corberán, M. Sanaú, and E. Peris, J. Am. Chem. Soc. 2006, 128, 3974-3979.

60. J. Wei, T. Ma, X. Ma, W. Guan, Q. Liu, and J. Yang, RSC Adv., 2014, 4, 30725-30732.

61. J. M. Fraile, J. I. García, C I. Herrerías, J. A. Mayoral, D. Carrié, and M Vaultier, Tetrahedron: Asymmetry, 2001, 12, 1891-1894.

62. U. Hintermair, J. Campos, T. P. Brewster, L. M. Pratt, N. D. Schley, and R. H. Crabtree, ACS Catal., 2014, 4, 99-108.

63. J. S. M. Samec, J.-E. Bäckvall, P. G. Andersson, and P. Brandt, Chem. Soc. Rev., 2006, 35, 237-248.

64. T. M. Gilbert, and R. G. Bergman, J. Am. Chem. Soc., 1985, 107, 3502-3507.

65. D. S. Glueck, L. J. N. Winslow, and R. G. Bergman, Organometallics, 1991, 10, 1462-1479.

66. V. Pons, and D. M. Heinekey, J. Am. Chem. Soc., 2003, 125, 8428-8429.

67. J. Campos, J. López-Serrano, E. Álvarez, and E. Carmona, J. Am. Chem. Soc., 2012, 134, 7165-7175.

68. S. Sato, R. Takahashi, T. Sodesawa, and N. Honda, J. Mol. Cat. A: Chem., 2004, 221, 177-183.

69. V. Lehr, M. Sarlea, L. Ott, and H. Vogel, Catalysis Today, 2007, 121, 121-129.

70. L.-Z. Tao, S.-H. Chai, H.-P. Wang, B. Yan, Y. Liang, and B.-Q. Xu, Catalysis Today, 2014, 234, $237-244$. 